\title{
English Grammar Teaching in the Context of Higher Vocational College in South China
}

\author{
Miao Jiang
}

Guangzhou Nanyang Polytechnic College, China

490979878@qq.com

\begin{abstract}
With the introduction of Communicative Language Teaching into China, whether grammar teaching is necessary or not and how to teach grammar teaching in EFL classroom puzzles many teachers. This paper identifies the important role in EFL learning and possible methodologies of grammar instructions. It also explores the students' and teachers' perceptions on grammar teaching as well as teachers' methodologies applied in EFL classroom in South China, through in-depth semi-structure interviews. The findings here indicate that teachers fail to do the systematic and effective grammar instruction. The article makes an attempt to suggest possible solutions with aid of modern information technology to achieve optimal grammar teaching based on the vocational college context in China.
\end{abstract}

Keywords: Grammar teaching, Context, Perceptions, Methods, Grammaring, Individualized instruction, Network Technology.

\section{INTRODUCTION}

The grammar teaching, originated from Latin and Greek teaching, predominate in the language teaching, both in language education research and classroom practice [1]. Since some new concepts and teaching methodologies was introduced into Mainland China in last 80 s or $90 \mathrm{~s}$, such as notions of communicative competence, the Communicative Language Teaching approach (CLT) and Task-based Language Teaching (TBLT), the central role of grammar teaching in the EFL classrooms has been challenged. Some teachers go from one extreme to the other extreme. Two reasons contribute to it: First, they taught grammar mainly before but they do not teach grammar at all now, for "Its effects are uncertain and hard to assess" [2] and "learners do not acquire what they have been taught" [3]. The effect of grammar teaching is disappointing. Second, learners have no enthusiasm in memorizing vocabularies and grammar structures. Therefore, the debate over that whether grammar teaching is necessary is still ongoing and the issue of how to teach grammar effectively confuses many EFL teachers in China.

\subsection{Puzzling}

Vocational English is a compulsory curriculum for students in higher vocational college. The curriculum emphasizes developing more speaking \& listening skills than reading and writing competence. However, grammar is essential for students, especially when they are required to pass some English exams such as PRETCO-B or CET-4. In the curriculum syllabus, teachers should teach grammar to enable them do better in the exam. But students show little interest and poor performance in it. Therefore, the author puzzled: how should teachers teach grammar students in higher vocational college effectively? What methodologies of grammar teaching can be used to improve students' interest and performance in grammar?

\subsection{Purpose of Study}

The best way to teach grammar in one context may not be the effective and best way to teach for learners from different context. So the empirical study is set in a private higher vocational college in South China, for it provides more evidences for current situations of grammar teaching. The understanding of it in the context can be the starting point for exploration of appropriate methodologies. Therefore, two issues are needed to be addressed:

- What are students and teachers' perceptions on grammar teaching?

- How do EFL teachers in GITC teach grammar in the EFL classroom? 
This essay aims to figure out the status quo of grammar teaching in GITC and make an attempt to explore contextual appropriately methods to improve grammar teaching.

\subsection{Significance of the Study}

For numerous English learners in China, grammar is the most learnt but is the most boring and disappointing. Hence, the present study is significant for both EFL teachers and learners in GITC and probably in other higher vocational colleges to change the undesirable current state.

\section{CONTEXT AND ISSUE}

\subsection{Students' Learning Situation}

Guangdong Innovative Technical College (GITC) is a private 3-year vocational college. Students in GITC have different levels of English proficiency. However, on the whole, they have undesirable English proficiency and show little motivation and interest in not only English learning, but also other subjects learning.

Many students started to learn English since grade 3 in their primary schools. However, little effect of about 10-year classroom grammar teaching has shown in students' oral and written performance. Many students have been learning English grammar for a decade, but they cannot use it appropriately in oral communication and written tasks.

\subsection{Background of Teachers}

There are $30 \mathrm{EFL}$ teachers in foreign language faculty, $85 \%$ of whom have obtained master's degree of English major with highest level of English proficiency.

Not all teachers receive formal teaching education and training. Every novice teacher has an opportunity to get initial teaching training in a Normal University in Southern, but in-service teachers rarely have formal and systematic training on English teaching.

Although mastering grammar is very important but bad grammar teaching experience makes many EFL teachers to quit grammar teaching, but focus on lexis teaching and speaking activities so as to achieve good classroom atmosphere and good evaluation from supervisors.

\section{LITERATURE REVIEW}

\subsection{Grammar and Grammar Teaching}

Grammar was considered as a set of rules [4], however, Larsen-Freeman [5] views grammar "as a skill rather than an area of knowledge" and coined the term "grammaring". As the fifth skill (The other four are: listening, speaking, reading and writing), grammar is not static, but dynamic, so language teachers should change the perception of grammar. Because the way of perceiving it will determine how it will be taught and learnt.

Ur [6] and Hedge [7] considers grammar teaching as simply presentation and practice in literature. Ellis refutes their parochial definitions of grammar teaching, and argued 4 aspects of grammar teaching: (1) either presentation or practice occurs in some lectures. (2) It can get learners to discover grammar structures on their own (none of presentation and practice). (3) It can provide learners comprehensible input and adequate "pool" of exemplars (none of presentation and practice). (4) It can also be implemented through "corrective feedback on learner errors" occur when participating in communicative tasks [8]

Swan [9] provides the main reason for grammar teaching in terms of comprehensibility. That is, successful grammar teaching will facilitate learners' understanding and being understood.

\subsection{Grammar Teaching Methods or Models}

There are many methods of grammar teaching. In this section, 5 grammar teaching methodologies or models will be reviewed and discussed. They are PPP model, implicit \& explicit teaching, consciousness-raising; focus on form and task-based instruction.

\subsubsection{PPP Model}

In the PPP (Presentation-practice-production) model, "a new grammatical structure is presented and explained, it is then practiced and finally students are expected to produce it in their own spoken and written discourse" [1]. It has been harshly criticized for its failure to follow the language acquisition order and achieve good grammar teaching effectiveness.

\subsubsection{Explicit and Implicit Teaching}

Implicit knowledge is knowledge we use spontaneously. It is "procedural" and is "held unconsciously" [3]. Explicit knowledge is knowledge we can explain. It is "consciously held, learnable and verbalisable" [3]. The object of grammar teaching can be described as enabling learners to use precise and appropriate grammar automatically [1]. The distinction explicit and implicit grammar teaching rests on whether the instruction is designed to induce learning without or with awareness.

\subsubsection{Implicit Teaching}

Ur [1] views that implicit teaching is the model that 
tries to duplicate the model of first language acquisition. That is, learners learn grammar subconsciously in the same ways as which they acquire their first languages. For example, have a large amount of exposure to authentic context. Krashen [10] is in favor of implicit grammar teaching in his Input Hypothesis. Language acquisition entails implicit grammar learning that can be achieved by means of exposure without consciousness. Long's Interaction Hypothesis [11] also involves implicit grammar learning. It points out that the negotiation of meaning in the interaction between learners and interlocutor with a higher level may lead to language acquisition. Swain [12] argues that "pushed out" in her Output Hypothesis enables learners to have chances to realize the gap between where the learner is and where the learner is going in communicative interaction. Exemplar-based model involves learning grammar implicitly as well. Its main idea is to provide abundant exemplars of formulaic language and combinations in order to enable learners to output language through analogy[13] [14].

\subsubsection{Explicit teaching}

Explicit grammar teaching has also some proponents. Swain [15] points out that "pushed out" needs to go with explicit feedback to master grammar better. Norris \&Ortega [16] justify that learners benefit more from explicit teaching. Ur [1] concludes that, for foreign language learners, explicit teaching through task-based method can largely facilitate their achievement of grammar accuracy.

\subsubsection{Advantages and Disadvantages}

Identifying the advantages and disadvantages of teaching grammar explicitly and implicitly can provide a reference for language teachers in their teaching practice. They are summarized respectively in Table 1 .

Table 1 the advantages and disadvantages of implicit and explicit teaching

\begin{tabular}{|c|c|}
\hline 3 & Explicit Teaching \\
\hline \multirow[t]{2}{*}{ Pros } & $\begin{array}{l}\text { Explicit knowledge may enable learners use } \\
\text { language more accurately and appropriately. }\end{array}$ \\
\hline & It attracts leaners' notice on forms or errors. \\
\hline Cons & $\begin{array}{c}\text { Good mastery of explicit knowledge may not } \\
\text { necessarily lead to use language }\end{array}$ \\
\hline 3 & Implicit -Teaching \\
\hline \multirow[t]{2}{*}{ Pros } & $\begin{array}{c}\text { Implicit teaching may increase leamers' motivation } \\
\text { to continue language learning. }\end{array}$ \\
\hline & $\begin{array}{c}\text { It is contextualized. Implicit knowledge is acquired } \\
\text { in certain context. So it enables leamers to use - } \\
\text { language spontaneously. }\end{array}$ \\
\hline Cons & $\begin{array}{c}\text { Leamers may not use language accurately and } \\
\text { notice their errors. }\end{array}$ \\
\hline
\end{tabular}

\subsubsection{Consciousness-raising and Focus on Form}

\subsubsection{Noticing}

Schmidt [17] summarizes that classroom instruction is helpful with noticing and that a degree of aware noticing plays an indispensible part in second language learning, because even a great deal of comprehensible input cannot be internalization if learners fail to notice it consciously. Then grammar learning or acquisition will not occur. Therefore, methods to increase learners' awareness of grammar features are worked out, such as consciousness-raising and focus on form.

\subsubsection{Consciousness-raising}

Thornbury [18] defines that consciousness-raising activities are what designed to enable learners to notice on grammar structures. Consciousness-raising activities designed by means of creating contexts so as to connected them and real life, or use role-playing to present. Nevertheless, these ways of presentation cannot necessarily lead to real grammar learning. The language learning process is a curve that has ups and downs rather than a linear process [19]. Conscious-raising reduces expectations, derived from PPP model, on learners to produce language instantly and accurately.

\subsubsection{Focus on Form}

Focus on form is suggested [20] and identified as "shift of attention to linguistic code feature" induced by questions which the instructor or leaners encounter within communicative activities [21]. The purpose of focus on form is to make learners notice grammar structures [1]. Focus on form is distinguished from focus on forms. Focus on forms is a grammar instruction method where the grammar itself is the main focus and where grammar items are instructed decontextualisedly one by one [20]. Thus, PPP model is a representative of focus on forms method in some degree. Ellis proposes two types of it: one is unplanned (reactive or incidental), the other is planned (preemptive). Unplanned focus on form concerns that the teacher teaches grammar to respond to errors that learners committed in their comprehension or production. Planned focus on form refers to that the teacher teaches grammar that they think learners probably have problems with, even if no error has been made in communicative tasks.

\subsubsection{Task-based Instruction}

A task-based activity must include following standards:

- Meaning is primary

- There is a goal which needs to be worked towards.

- The activity is outcome-evaluated. 
- There is a real-words relationship

Even though definitions of the pedagogical task are slightly different, they all highlight the truth: characterized communicative language use, pedagogical tasks focus on expressing meaning, not deploying grammatical form [23]. Swain [12] proposes that task-based instruction work best for learners with high proficiency. As a method to teach grammar, however, task-based instruction is criticized that learners may employ simple and basic words and sentences to complete the task, thus, little grammar learning can be elicited [24].

\subsection{Individualized instruction and Computer Network Technology}

Computer network technology has become an effective tool to promote the education reform of College English and individualized teaching in China. Ministry of Education of China encourages the construction and use of MOOC in 2015, for it enables educators to trace students' learning process, understand learning style and give them individualized guidance and help based on analysis of big data. So, individualized teaching can be achieved through digital technique. Flipped classroom changes "one-size-fits-all" teaching mode and provides opportunities to personalized learning and active learning.

\section{METHODOLOGY}

The study adopted a qualitative approach interview method. The qualitative approach involves "authenticity and voice and interpretations of situations and behavior" and semi-structure interview ensures participants of chances to "develop their response in their own way" [24]. So the research method fits my research aim well in order to get in-depth understandings of students and teachers' beliefs, perceptions or personal experience [25] on grammar teaching. Data was collected through semi-structured face to face interviews with $2 \mathrm{EFL}$ teachers and 2 students, who were/are teaching or learning the Vocational English. Purposive sampling [27] was followed: Teacher A is an experienced teacher with 11 years teaching experience and Teacher B has 4 years teaching experience. Student $\mathrm{A}$ is the intermediated English level and Student B, the initial level. These participants represent different groups and can be good informants with self-reflections and thinking on grammar teaching and learning.

\subsection{Data Collection and Analysis}

The consent information was obtained from participants and from interview setting-GITC and participants were anonymous to guarantee confidentiality. I tried to avoid bias and be transparent. The native language of participants, Chinese, was used to achieve clear understandings. Individual interviews took 10 minutes for each participant. Interviews with teachers based on their perceptions and ways of teaching grammar and the interview with students based on their views and experiences in grammar learning. Interview questions derived from those identified by Kvale and Brinkmann [28] were used to elicit their response and discussion. The data was recorded, transcribed verbatim, translated and member-checked.

The interview data collected were analyzed in inductive way and could be categorized into several themes:

-Students' and teachers' perceptions of grammar instruction in GITC

- The methodology is applied by EFL teachers for grammar teaching

-Effect of grammar teaching

\subsection{Research Limitations}

This research has limitations in sampling and interview questions. Their beliefs and ideas cannot stand for all the other teachers and students from the vocational college. I was not able to do multiple interviews with the same participants so as to get rich data.

\section{FINDINGS}

\subsection{Students and teachers' perceptions}

Students may show little passion for learning grammar such as grammar structures, lexis, etc. This causes not much grammar teaching in the EFL classroom. Teacher $\mathrm{C}$ illustrated the reason why she gave little grammar instruction as follows:

Teacher C: I teach not much grammar; because I ... do not know how to teach grammar...students feel bored and they seem to be not interested in grammar.

But numerous students recognize the importance of grammar, as the Student A stated:

Student A: .....Mastering more grammar structures may improve oral English proficiency. Grammar teaching is helpful for listening, speaking, reading and writing.

In terms of grammar teaching, students with different English level have different views:

Student A: Students who are interested in English probably like grammar teaching. The key is to motivate those who have no interest. 
Student B: I think interest developing comes before grammar teaching.

\subsection{PPP model and explicit teaching}

Informed by teachers of participant, their grammar teaching entails PPP model and explicit teaching, among which PPP is applied most. Students are asked to do a great deal of grammar exercises until they can master what is instructed. Teacher A and teacher B respectively described how they taught grammar:

Teacher A: Every unit of textbook we used has a topic. Vocabularies and sentence patterns relevant to the topic are taught. I usually instruct words, expression and sentences much more... using explanation and providing.... some examples containing a grammar rule and get them to work out the rule in groups. They seem are more motivated and engaging.

Teacher B: I only teach grammar points appear in previous exam papers...provide examples...and then make them to drill and practice.

EFL teachers in GITC have no systematic plan for grammar teaching, and they instruct grammar when they encounter it or occasionally in response to problems arisen in learners' oral or written output. Teachers tend to use implicit feedback in response to students' errors in order to sustain students' motivation. For example, Teacher A recasts what students have said to respond students' error, as she mentioned:

I repeated his or her utterance in correct form.

\subsection{Unsatisfactory effect of grammar teaching}

The effectiveness of their grammar instruction is unsatisfactory, although teachers work hard. Even some students have awareness of learning, but they still do not understand and commit errors after instruction. Teacher $\mathrm{A}$ and $\mathrm{B}$ commented as below:

Teacher A: ...Students still make mistakes on grammar just taught.

Teacher B: ...But students do not listen carefully to my grammar instruction. For the effect, I am not sure.

\section{DISCUSSION}

The findings have illustrated unsatisfactory current situation of grammar teaching. The reasons of are analyzed and elaborated with GITC context and notions reviewed. Further, the suggestions to improve its effectiveness are made on the basis of the reasons.

\subsection{Reasons}

Two reasons contribute to the unsatisfactory effect: teachers' misconceptions on grammar teaching and language learning process, and traditional and effective approach.

Teachers considered grammar as a kind of knowledge and a static system of sentence-level rules [5]. And misunderstand language development as a "mechanistic, linear and input-output" process [18], influenced by the perceptions underlying in the PPP model. They ignore the even language learning process and expect learners to not only intake and output what they have been taught, but also has immediate and consistently accurate production. In addition, students' knowledge of a grammatical rule does not convert into accurate and fluent application in oral or written communication. Students still commit errors regardless of a great deal of grammar explanations and exercise. Larsen-Freeman [5] defines the problem as "the insert knowledge problem". So they get frustrated and complain their careful lesson plans cannot be processed well and students in GITC are so hard to teach. Teachers' frustration leads to little grammar instruction in their classes.

Due to the marginalization of grammar and rare systematic in-service training on EFL teaching, teachers lack rich theories in grammar teaching and training opportunities. Some of them such as Teacher B, choose to avoid grammar teaching or teach grammar in the way which is guided by the imitation and the underlying misconception on grammar. The PPP teaching model is adopted the most frequently. However, as argued before, PPP model was evidenced to be a least effective one, for it is incompatible with learners' acquisition order, that is, it does not take learners' readiness into consideration.

To summarize, it is not hard to explain why the grammar instruction in GITC is inefficient.

\subsection{Suggestions}

In this section, the author makes an attempt to provide suggestions for grammar teaching practice in combination with the context. What is talked about above suggests that there is a need for a change in teachers' conceptions and grammar teaching method. Alternative teaching methods to PPP model is required to improve students' motivation and effectiveness in grammar teaching. Modern information technology also is advised in or out of EFL classroom to facilitate English grammar teaching,

\section{- Grammaring}

The conventional perspective on grammar should be changed into grammaring. The deliberate application of grammatical features will sharpen the grammaring skill and enhance learners' innovation rather than imitation if they are conscious "not only of rules, but also of reasons" [5]. Furthermore, vocational college students prefer practical learning to knowledge accumulation by 
rote. Obviously grammaring is much more compatible with the characteristic of students in GITC.

In addition, language teachers should follow language development. The zero tolerance attitudes toward learners' error need to be changed. It is unrealistic and harmful to demand second language learners (other than children) to achieve fluency and accuracy as native speakers [2].

- Exemplar-based model

Learners in GITC and other vocational colleges like "fun" learning and discussed that implicit teaching increases students' learning motivation and appropriate language use automatically. Teachers provide authentic examples illustrating grammatical features for learners through computer network technology, for example, prefabricated phrases, expressions, songs, video clips, poetries, stories and dramas, etc, Learners are encouraged to familiar with or memorize them and expose themselves, outside of class, to English newspapers, journals and novels, etc. A repertoire of formulaic language provided enables learners to acquire grammar in relaxed and pleasant way, as Cook [29] put the way into "play". However, they study not much after class. EFL classroom becomes the only chance to be exposed to the target language. Short "fun" activities and games [1] in class work well to interest and motivate initial learners to grammar learning.

\section{- Conscious-raising}

To solve learners' distraction at the time of grammar teaching, teachers can supply sentences or passages illustrating a grammatical feature and ask to figure out it from the input. Conscious-raising is able to raise learners' awareness of grammar structures.

- Integrating focus on form into task

A lesson can be designed like this: the communicative task is the focus, and grammar has some place in it [23]. In other words, teachers occasionally give implicit or explicit instruction on grammatical forms what can serve for the communicative activity. In overall, the lesson focuses on meaning. The task plus focus on form establishes links grammatical features with real communication and enables leaners to know and use the form by.

\section{- Task-based Instruction}

Task-based grammar instruction focuses on its use, rather than its form. The communicative tasks' components such as "problem-solving, interactive group work or role-play" [1] enables learners in GITC more interested and engaged in grammar leaning. Although many suggest that the communicative task is fit for advanced and motivated learners, it is useful for learners to not only use freely grammatical structures that they have learnt to complete tasks, but also acquire grammatical structures from peers through negotiation of meaning in interactions, and notice what they have not known.

It is necessary for teachers to select appropriate above methods on the basis of teaching context and considerations. Teachers should not confine one teaching method of them, "but use most or all in varying proportions" [1], since multimode grammar teaching is convinced to generate the best result [30].

- Net-work based individualized instruction

Net-work based personalized learning methods, such as MOOCs and flipped classroom are suggested to meet different learning needs, style and English proficiency. Through the net-work based learning, students have much more confidence and interest in grammar, and teachers can give more targeted grammar instruction.

\section{CONCLUSION}

To conclude, on the opposition of traditional definition, grammar is a dynamic skill not a static set of rules. It is an essential part in grammar learning. Grammar teaching is necessary for foreign language learners, for efficient grammar teaching helps learners with comprehension and production. Thus, 5 methods or models for grammar teaching were reviewed respectively: PPP, implicit and explicit teaching, consciousness-raising, focus on form and task-based instruction. This study investigated the current situation of grammar teaching in GITC and made an attempt to propose possible solutions to achieve optimal grammar teaching based on GITC context and teaching methodologies reviewed. EFL teachers in GITC need to shift the traditional concepts on grammar to grammaring and follow the language development to guide their teaching. Alternative teaching methods to PPP model were also suggested aim to provide a reference for teachers to make a change. They can use one of them or mixed most of them together, with the aid of modern information technology for better. However, how teachers adopt net-work based teaching methods wisely and reasonably is encouraged to study.

\section{ACKNOWLEDGMENTS}

This paper is the phased research result of the general project "Research on the Path of Business English 'Curriculum Ideology and Politics' Based on the Concept of Cross-border and Integration" (2020GZYB87) in 2020 of the 13th Five-year Plan for the Development of Philosophy and Social Sciences in Guangzhou and the project $1+\mathrm{N}$ Cambridge Business English (NY-2019CQ2KC-51), Business English Brand Major (NY-2019CQZY-02) and Business English Teaching Team (NY-2018CQ2TD-02) of Guangzhou Nanyang Polytechnic Vocational College in 2019 and 2018. 


\section{REFERENCES}

[1] Ur, P., Grammar teaching: research, theory, and practice, In Hinkel, E. (Ed.), Handbook of research in second language teaching and learning, Routedge, 2011, pp. 507-522.

[2] Swan, M., Does teaching grammar work? Modern English Teacher, 2006, 15(2), pp. 5-13.

[3] Ellis, R., Current issues in the teaching of grammar: an SLA perspective. TESOL Quarterly, 2006, 40(1), pp. 83-107.

[4] Ur, P., A course in language teaching: Practice and theory, Cambridge: Cambridge University Press, 1996.

[5] Larsen-Freeman, D., Teaching language: from grammar to grammaring, 2003, Heinle.

[6] Ur, P., A course in language teaching: Practice and theory, Cambridge: Cambridge University Press, 1996.

[7] Hedge, T., Teaching and Learning in the Language Classroom, 2000, Oxford University Press.

[8] Ellis, R., Current issues in the teaching of grammar: an SLA perspective. TESOL Quarterly, 2006, 40(1), pp. 83-107.

[9] Swan, M., Does teaching grammar work? Modern English Teacher, 2006, 15(2), pp. 5-13.

[10] Krashen, S., Principles and practice in second language acquisition, 1982, England: Pergamon.

[11] Long, M. H., The role of the linguistic environment in second language acquisition. In W. Ritchie \& T. Bhatia (Eds.), Handbook of second language acquisition, San Diego, CA: Academic Press, 1996, pp. 413-468.

[12] Swain, M., The output hypothesis: Theory and research, In E. Hinkel (Ed.), Handbook of research in second language teaching and learning, Oxford University Press, 1995, pp. 471-484.

[13] Ellis, N., Frequency effects in language process. Studies in Second Language Acquisition, 2002, 24(2), pp.143-188.

[14] Wray, A., Formulaic sequences in second language teaching: Principle and practice, Applied Linguistics, 2002, 21(4), pp. 463-489.

[15] Swain, M., French immersion research in Canada: recent contributions to SLA and applied linguistics, Annual Review of Applied Linguistics, 2000, 20(20), pp.199-212.

[16] Norris, J. M., \& Ortega, L.. Does type of instruction make a difference? Substantive findings from a meta-analytic review. Language Learning, 2001, 51, Supplement 1, pp.157-213.

[17] Schmidt, R., Attention. In P. Robinson (Ed.), Cognition and second language instruction, Cambridge University Press, 2001, pp. 3-32.

[18] Thornbury, S., Uncovering grammar, Macmillan Heninemann, 2001, pp.31-42.

[19] Larsen-Freeman, D., Chaos/complexity science and second language acquisition. Applied Linguistics, 1997, 18(2). pp. 141-165.

[20] Long, M. H., Focus on form: A design feature in language teaching methodology. In K. de Bot, R. Ginsberg, 8c C. Kramsch (Eds.), Foreign language research in cross-cultural perspective, Amsterdam: John Benjamins, 1991, pp. 39-52.

[21] Robinson, P., \& Long, M. H., Focus on Form: Theory, research and practice. In C. Doughty and J. Williams (Eds.) Focus on Form in Classroom Second Language Acquisition. Cambridge: Cambridge University Press, 1998, pp. 15-42.

[22] Skehan, P., A cognitive approach to language learning, Oxford University Press, 1998, pp.268.

[23] Nunan, D., Task-based language teaching, Cambridge: Cambridge University Press, 2004.

[24] Seedhouse, P., Task-based interaction. English Language Teaching Journal, 1999, 53(3), pp. $149-156$

[25] Campbell, A., McNamara, O., \& Gilroy, P., Practitioner research and professional development in education, Paul Chapman, 2004, pp.24-99.

[26] Park, M. \& Sung, Y., Teachers' perceptions of the recent curriculum reforms and their implementation: what can we learn from the case of Korean elementary teacher?, Asia Pacific Journal of Education, 2013,33 (1), pp.15-33.

[27] Patton, M.Q., Qualitative Evaluation and Research Methods, (2nd Ed.), Newbury Park, CA: Sage, 1990.

[28] Cook, G., Language play, language learning, Oxford University Press, 2002.

[29] Kvale, S., \& Brinkmann, S. Interviews: Learning the craft of qualitative research interviewing, London: Sage, 2009.

[30] Ellis, R., The Study of Second Language Acquisition (2nd Ed.), Oxford University Press, 2008 